\title{
Geleneksel Kemaliye Evlerine Ait Kapıların Incelenmesi
}

Öğr. Gör. Serdar Keskin

Makale Geliş Tarihi: 06.II.2015

Prof. Dr. Kemal Yıldırım

Yayına Kabul Tarihi: 20.06.2016

\section{Öz}

Bu çalışmada, Erzincan iline bağlı Kemaliye (Ĕğin) ilçesinde bulunan geleneksel evlere ait kapıların koruma durumu, mimari ile uyumu, süsleme ve aksesuar durumu, kapıların bozulma durumu, kapıların ölçüleri, kapı yapım tekniği ve kullanılan ağaç türünün tespit edilmesi amaçlanmıştır. Bu amaçla, Kemaliye kentsel sit alanında bulunan 100 tescilli yapının kapıları araştırma kapsamına alınmıştır. Evlerin adres bilgileri, mülkiyet durumları, fotoğrafları ve evlere ait kapıların özellikleri, ölçüleri gibi bilgiler her bir kapı için ayrı ayrı oluşturulan envanter formlar üzerinde toplanmıştır. Sonuçta, incelenen Kemaliye evlerine ait ahşap kapıların bozulmalara karşı korunması gerektiği ve uygulanan üst yüzey işlemlerinin standartlaşmasının yararlı olacağı kanısına varılmıştır.

Anahtar Kelimeler: Geleneksel Evler, Kemaliye Evleri, Ahşap Kapılar

\section{THE INVESTIGATION OF DOORS BELONGING TO TRADITIONAL KEMALIYE HOUSES}

\begin{abstract}
In this study, the protection capacity of the traditional houses' doors of Kemaliye (Eğin), one of the counties of the city Erzincan, their adaptation with the architecture, situation of ornament and accessory, deterioration levels, measurements of the doors, techniques of how to make a door and determination of the tree species used in are aimed. For this purpose, the doors of hundred registered houses in the protected urban area of Kemaliye are included to the study. The information like addresses of the houses, ownership status, photographs, the features and the measurements of these houses' doors are presented separately for each door in inventories. Consequently, it is concluded that the doors of the analyzed Kemaliye houses should be protected against the deterioration and the standardization of the applied surface layer treatments would be beneficial.
\end{abstract}

Keywords: Traditional Houses, Kemaliye Houses, Wooden Doors

\footnotetext{
Öğr. Gör. Serdar Keskin, Erzincan Üniversitesi, Kemaliye Hacı Ali Akın Meslek

Yüksekokulu, Mimarlık ve Şehir Planlama Bölümü, Mimari Restorasyon Programı, Erzincan.

E-posta: serdarkeskin1980@hotmail.com

Prof. Dr. Kemal Yıldırım, Gazi Üniversitesi, Teknoloji Fakültesi, 


\section{Giriş}

Anadolu'da yeni bir mekân kimliğini ortaya koyan Geleneksel Türk evinin dayandığı kaynaklara ulaşabilmek için, "taşınabilen mekân" düşüncesine dayanan, eski gelenekten yararlanmak öncelikle gereklidir. Bu ilginç mekân geleneği, özellikle odaları, iç düzeni ve teknolojisi ile "kolayca kurulup sökülebilen ve taşınan çadır evlerin" önemli izlerini taşımaktadır. Anadolu'da biçimlendirilen Türk evinin kaynaklarına bu açıdan bakılınca, yüzyıllarca süregelen bir yaşama geleneğinin, ilkeleri, kavramları ve biçimleri ile bağlantılı olduğu görülür (Küçükerman ve Güner, 1995: 1-320). Geleneksel Türk evlerinin hemen hemen hepsinde uygulanan iç, orta ve dış sofalı plan tipinde sofa etrafına eklemlenen odaların günlük yapılan birçok eylemin gerçekleşmesine imkân tanıyan donanıma sahip olması ortak özellikleridir. Her bir oda oturma, misafir ağırlama, dinlenme, yatma, yemek yeme, sokağı çok rahat görebilme, giysi- eşya vb. depolama, ısınma, yıkanma gibi eylemlerin çok rahatlıkla gerçekleştirilmesine olanak tanır (Hacıbaloğlu, 1989: 1-35).

Geleneksel Türk evine yönelik çok sayıda çalışma yapılmasına karşın bu eşsiz evlerin avlu, giriş ve oda kapılarını detaylı ele alan çalışmaların sayısının sınırlı düzeylerde kaldığı görülmektedir(Şaşmaz, 2002; Kahraman, 2004; Yıldııım, 2006; Yıldırım ve ark. 2006; Kılıç, 2010). Kemaliye evleri özelinde Alper (1990) tarafından yapılan kapsamlı çalışmada ise daha çok Kemaliye yerleşme dokusu ve evlerin genel özellikleri üzerine durulmuştur. Literatürden, bu bölgedeki evlerin giriş ve oda kapılarının spesifik olarak bilimsel çalışmalara konu edilmediği anlaşılmaktadır. Oysaki Kemaliye'nin zengin kültürü ve tarihe meydan okuyan evleri ile bu evleri hem görsel hem de işlevsel olarak değerli kılan kapılarının araştırılmasına ve elde edilen bulguların gelecek nesillere aktarılmasında büyük yarar vardır.

Mimarlıkta kapı sözcüğü yaygın olarak mekânı sınıllayan düşey yüzeylerde (duvar) bırakılan boşluk ve o boşluğu denetlemek üzere görevlendirilen hareketli öğe (doğrama) olarak tanımlanır. Tarihsel örneklerde de görüldüğü gibi dış kapı gerek geçişi sağlama ya da kesme (denetleme) işlevi açısından, gerekse de simgesel yönden yapıda özel bir konumdadır (İzgi ve Aysel, 2003: 11-207). Insanların yerleşik hayata geçmesiyle birlikte mekâna giriş ve çıkışı sağlayan kapılar, mimari yapının en önemli elemanı olmuştur (Öztürk, 2003: 1).

Geleneksel evlerin kapıları genellikle büyük ve iki kanatlıdır. Bahçe duvarı içine açılan kapıların üzeri çoğu zaman saçaklı yapılmıştır. Kanatlar som veya aynalıdır. Kapı evin sembolüdür (Eldem, 1955: 1-50). Konu alanını oluşturan Geleneksel Kemaliye (Eğin) evlerinin genel özellikleri kısaca 
aşağıda açıklanmıştır.

Anadolu'nun pek çok kentinde görülen ahşap ağılıklı geniş sundurmalı çatısı olan küçük yayvan yarım daireli kiremit-tuğlaların çatısını süslediği evlere (Parlar, 2002: 453-464), Kemaliye ilçesinde de yaygın olarak rastlanmaktadır. Bu evler, Anadolu'nun her yerinde küçük farklılıklarıyla geniş uygulama imkânı bulmuştur (Yıldırım ve ark., 2006).

Kemaliye'de 16.yy. da oluşan fiziksel doku, artan nüfusa bağlı olarak giderek sıklaşan yapılanma düzeniyle 19. yüzyıla ulaştığı sonucuna varılabilir. Kemaliye bu 19. yüzyıl yerleşme dokusunu değişmeden günümüze değin koruyabilmiştir (Alper, 1990).

Kemaliye evlerinin oluşumunda ana unsur topografyadır. Kademelendirilmiş araziye konumlandırılan evler araziyi verimli kullanabilmek için çok katlı ve doğayla uyumlu malzemeden inşa edilmiştir. Kemaliye evlerinde sokak yalnızca giriş düzeyinde ilişki kurarken öncelikle yönlenmesi gereken dış çevre öğesi değildir, ana görsel yönlendirici Fırat Nehri'dir (Kemaliye Kaymakamlığı, 1996: 54-59). Yollar arazinin topografik verilerine göre eğime dik ve paralel biçimlenmektedir. Eğime paralel sokağın yükselen kenarındaki konutlar, sokak siluetine ön cephesiyle katılırken; alçalan kenardaki evler sokakla ilişkisini arka cephesiyle kurmaktadır. Sokağın iki silueti birbirinden farklılık gösterir, sokağın bir tarafındaki evler tek veya iki katlı görünürken diğer tarafındaki evler üç veya dört katlı görünmektedir. Eğim yönüne dik sokaklarda ise kat yüksekliği açısından simetrik siluetler vermektedir. Sokağı her iki yönde de evlerin yan cepheleri sınırlamakta, böylece sokak her iki yanda benzer cephe özellikleri sunmaktadır (Alper, 1990: 59-61).

Kemaliye evlerinde kat adedini yapının eğimli arazideki konumu belirlemektedir. Evlerin tümünde iki kat bulunur. Bu iki kata ek olarak kaçak kat bulunur. Ana katın üstünde taban alanının yaklaşık yarısı kullanılarak yapılmıştır. Bazı evlerde ikinci bir alt kat (yer katı) bulunmaktadır. Dolayısıyla kat adedi dört katla sınırlanmıştır. Kemaliye kat dokusunun ayırtkan özelliği; Evlerin tümüne yakın bölümünde kaçak kat dışında katların doğrudan dış çevre ile ilişkisinin sağlanabilmesidir. Evlere ana katlarda arka cepheden, alt katlarda ise ön ve yan cepheden giriş sağlanmaktadır (Alper, 1990: 59-61).

Kemaliye evlerinde dış kapı, yapının giriş aksının ortasına oturtulmuştur. Daha büyük hacimli evlerde ise iki giriş kapısı bulunmaktadır. İç mekânın ışık alması için kapının üstüne ahşap pencereler konumlandırılmışır. Kapı kanadı yatay konumda bulunan iki ahşap kuşağa çivilerle yan yana çakılmış düşey geniş ahşaplardan oluşmuştur. Dış kapılar üzerinde ki en önemli 
unsur zengin motiflerden oluşan dövme demirden yapılmış olan kapı tokmaklarıdır. Eve gelen misafirin kadın veya erkek olduğunu anlamak amacıyla kalın ve ince ses çıkaracak şekilde üretilmişlerdir. Oda kapıları genel olarak tek kanatlı olarak yapılmış ve sadedir (Alper, 1990: 59-61).

20. yy. endüstriyel üretimde, seri üretime uygun yeni ahşap kapı tipleri ortaya çıkarken, aynı zamanda birçok olumsuzluklarına rağmen, gerek güvenlik açısından (çelik kapılar), gerekse de seri üretime uygunluğu, ekonomik oluşu, bakım istememesi, dönemin mimari görünümüne daha uygun olması gibi nedenlerle alüminyum, PVC, temperli özel cam vb. malzemelerden üretilen doğramalar, ahşap doğramalara göre daha yaygın kullanılır olmuştur (İzgi ve Aysel, 2003: 11-207). Hâlbuki geçmişte sahip olduğumuz ve yok olmaya yüz tutmuş geleneksel kapıların detay ve tekniklerinin korunarak sahip çıkılması, yeni önerilerde, belki yorumlanarak, yaşatılabilmesi sağlanmalıdır (Yıldıım, 2006: 1). Bu çalışmada, Geleneksel Kemaliye evlerinde kullanılan kapıların malzemeleri, yapım teknikleri, boyutları, aksesuar ve süsleme özelliklerinin tespit edilmesi amaçlanmıştır.

\section{Yöntem}

\subsection{Araştırma Ortamı}

Bu çalışmada, Geleneksel Kemaliye kentsel sit alanında bulunan evlerin bahçe, giriş ve oda kapıları araştırma kapsamına alınmıştır. Araştıılan evlerin Kemaliye kentsel sit alanında bulunması ve yapının tescilli olması tercih edilmiştir. Bu özelliklere sahip 100 evde kullanılan kapıların malzemeleri, boyutları, yapım tekniği, süsleme ve aksesuar durumları, kapıların koruma ve bozulma durumları, kullanılan ağaç türü ve kapı açılma yönleri incelenmiştir. Araştırma verileri envanter form üzerine işlenmiş, kapıların fotoğrafları çekilmiş ve çizimleri yapılarak belgelenmiştir.

\subsection{Envanter Form Geliştirme}

Daha önce Şaşmaz (2002), Kahraman (2004) ve Kılıç (2010) tarafından geliştirilen ve benzer araştırmalarda kullanılan envanter formlarından faydalanılmış, araştırmanın amacına uygun yeni bir envanter form geliştirilmiştir. Yeniden düzenlenen envanter form üzerinde yapının işaretli pafta numarası, karar no, pafta/ada/parsel numaraları gibi yapıyla ilgili daha detaylı bilgilere yer verilmiştir. Ayrıca, yapıda kullanııının meydana getirdiği değişiklikleri ve kazandırılan işleve uygunluk amaçlı değişimleri içeren yapının mülkiyet durumu, yapının özgün ve bugünkü kullanımları eklenmiştir. Yine bu çalışma yalnızca tescilli yapılar üzerine olduğu için yapının tescil tarihi envanter forma eklenmiştir. Bu form 2015 yılının Mayıs 
ve Haziran aylarında araştırma yapılan evlere gidilerek bizzat yerinde doldurulmuştur. Araştırma kapsamına alınan evlerin kapıları için düzenlenen envanter form dört bölümden oluşmaktadır (Tablo 4, Bkz. Ekler).

a) Kapının bulunduğu ev ile ilgili genel bilgiler; kapı kod numarası, evin adres bilgileri, ev sahibinin adı, plan tipi, tescil tarihi, işaretli pafta numarası, karar numarası, evin genel durumu, kapının türü, yapının mülkiyet durumu, yapının özgün ve bugünkü kullanımı.

b) Kapıların durumu ile ilgili bilgiler; kapının koruma durumu (kanat, kasa, menteşe, tokmak koruma durumları ve mimari ile uyum, süsleme ve aksesuar durumu, kapı bozulma durumu (çatlama, çarpılma, çürüme).

c) Kapı ölçülerine dair bilgiler; kapı kanat ölçüleri, kapı boşluğu ölçüleri.

d) Kapının yapım özellikleri; yapım tekniği, kullanılan ağaç türü, kapının açılma yönü.

\subsection{Fotoğrafla Belgeleme}

Bu çalışmada aşağıdaki amaçları gerçekleştirebilmek için fotoğrafla belgeleme çalışması yapılmıştır.

a) Kapıların elemanlarını ve aksesuarlarını ayrıntıı bir şekilde saptamak,

b) Araştırma esnasında yorumlanması güç olan kısımları sonradan değerlendirmek,

c) İncelenen kapıları belgelemek,

d) Form doldurulurken unutulan veya eksik kalan kısımları kontrol etmek.

\subsection{Kapıların Çizimi}

Araştırma kapsamına alınan evlerin kapılarının yükseklik, genişlik, derinlik ve kanat kalınlık değerleri ile kapılar üzerindeki süslemeler ve aksesuarların boyutları ölçülerek çizelgelere işlenmiştir. Daha sonra kapılar tespit edilen veriler ışı̆̆ında AutoCAD programıyla çizilmiştir (Şekil 4-10, Bkz. Ekler). Şekil 4'te sırasıyla bahçe, giriş ve oda kapılarında bulunan kapı tokmaklarının çizimi, Şekil 5 ve Şekil $6^{\prime}$ da Kemaliye evlerinin kapılarında görülmeyen süsleme örneklerini barındıran evlerin kapılarının çizimi, Şekil 7'de tek kanatlı giriş kapısı örneği, Şekil 8'de kanat genişliği eşit olmayan çift kanatlı kapı örneği, Şekil 9'da kanat genişliği eşit olan çift kanatlı kapı örneği, Şekil 10'da ise oda kapısı örneğinin çizimleri yapılmıştır. 


\section{Bulgular}

Araştırılan evlerin bahçe, giriş ve oda kapıları incelenmiştir. Tescilli yapıların \% 10'una çeşitli nedenlerden dolayı (kayıtlı adresin yanlış olması, yüksek bahçe duvarı ile çevrilmiş olması, ev ile ilgili yıkım kararı alınmış olması vs.) ulaşılamamıştır.

\subsection{Kapıların Korunma Durumu}

Araştıılan evlerin giriş kapılarının 10 tanesinde özgün ahşap kapılar yerine metal kapılar kullanıldığı tespit edilmiştir. Ahşap kapıların kanatları genel olarak iyi korunmuş olmasına karşın bir kısmının korunma yönünün zayıf olduğu görülmektedir. Bahçe kapılarının diğer kapılara oranla daha az korunduğu gözlemlenmiştir. Kapı kanatları kasaya nazaran daha az korunmuştur. Menteşe olarak kullanılan dövme demirden yapılmış olan güllaplar kanatların kasayla bağlantısını gerçekleştirmektedir. Güllap kullanılmayan kapıya dair bulgulara rastlanmazken güllaplarda korozyona bağlı bozulmalar mevcuttur. Kapı tokmaklarının ise kendine özgü bir tasarımı ve eve kattığı kültürel, işlevsel değerlerle birlikte günümüze kadar korunduğu tespit edilmiştir. Oda kapılarında kullanılan tokmak veya halkalar giriş kapısı ve bahçe kapılarında kullanılan tokmak veya halkalara göre daha küçük boyutlardadır. Kapı tokmaklarının çoğunluğu yenilenirken özgün tokmaklarda korozyon olduğu tespit edilmiştir (Şekil 4, Bkz. Ekler). Kapılar mimariyle genel olarak uyumludur (Şekil 1).

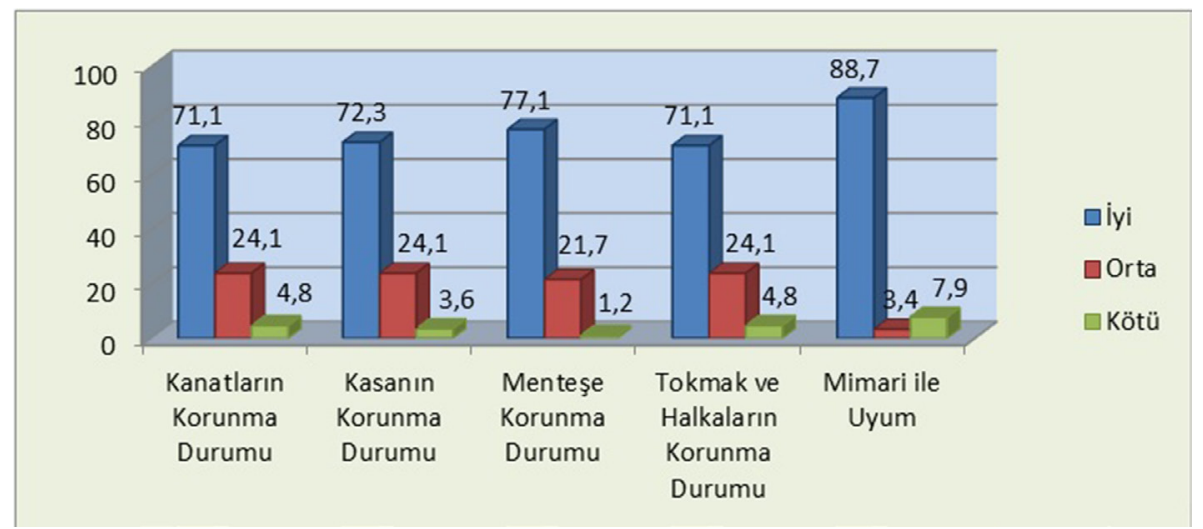

Şekil I. Kemaliye evlerinde kapıların korunma durumu grafiği 


\subsection{Kapıların Süsleme ve Aksesuar Durumu}

Kapılarda süsleme veya bezeme öğesi kanatlarda görülmezken, kanatları düşey olarak yan yana gelmesini sağlayan ahşap binilerde ve bazı evlerin kapı pervazlarında süsleme öğelerine rastlanmıştır. Çok az evin kapısında görülen bu süslemeler valnızca bahce kapılarında gözlemlenmistir.

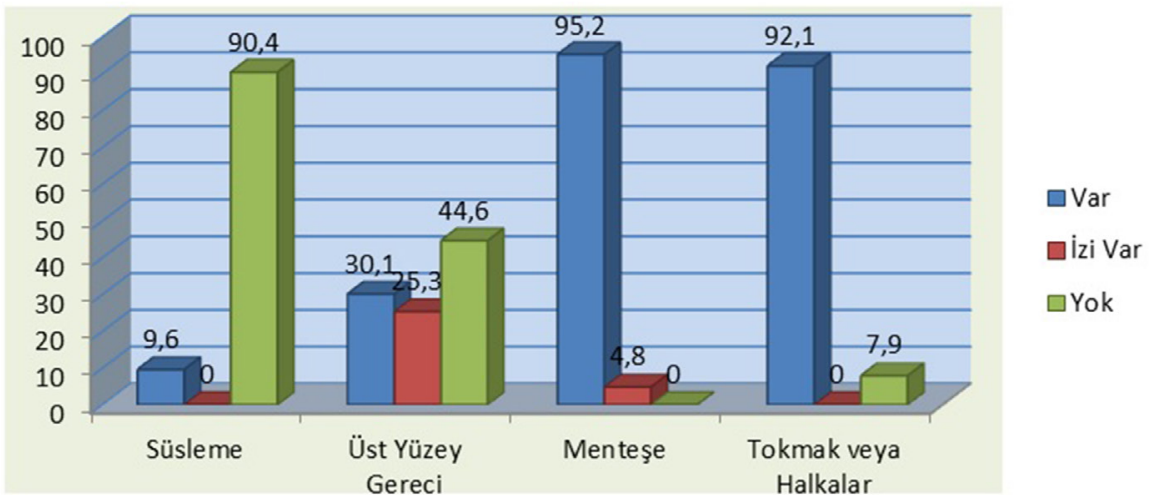

Şekil 2. Kemaliye evlerinin kapılarında süsleme ve aksesuar durumu grafiği

Restorasyonu yapılan evlerde üst yüzey işlemlerinin yapıldığı görülmüş, diğer evlerde ise yüzey koruma malzemelerinin zamanla yok olmuş veya izi kalmıştır. Bazı evlerin giriş ve bahçe kapılarında ise yağlı boya uygulaması ile kapılar boyanmıştır (Şekil 2).

Ulaşılan bilgilere göre ahşap kapıların \%61,4'ünde yalnızca orijinal kilit kullanıldığı, \% 19,3'ünde hem orijinal hem de sonradan takılan kilidin bir arada kullanıldığı, \% 19,3'ünde ise orijinal kilidin tamamen değiştirilerek sonradan başka bir kilit takıldığı tespit edilmiştir.

\subsection{Kapıların Bozulma Durumu}

Araştırılan evlerin kapılarının bozulma durumları Tablo 1 'de verilmiştir. Buna göre, bahçe kapılarının \% 21,4'ünde çatlamaların, \% 3,6'sında çarpılmaların ve \%10,7'inde ise çürümelerin fazla düzeylerde olduğu görülmektedir. 


\begin{tabular}{|c|c|c|c|c|c|c|c|}
\hline \multirow{2}{*}{\multicolumn{2}{|c|}{$\begin{array}{l}\text { Kapı Kanatlarinın } \\
\text { Bozulma Durumları }\end{array}$}} & \multicolumn{2}{|c|}{ Çatlama } & \multicolumn{2}{|c|}{ Çarpılma } & \multicolumn{2}{|c|}{ Çürüme } \\
\hline & & n & $\%$ & $\mathbf{n}$ & $\%$ & $\mathbf{n}$ & $\%$ \\
\hline \multirow{3}{*}{ Bahçe Kapısı } & Fazla & 6 & 21,4 & 1 & 3,6 & 3 & 10,7 \\
\hline & Biraz & 9 & 32,1 & 9 & 32,1 & 2 & 7,2 \\
\hline & Yok & 13 & 46,5 & 18 & 64,3 & 23 & 82,1 \\
\hline \multirow{3}{*}{ Giriş Kapısı } & Fazla & 6 & 8,2 & 2 & 2,7 & - & - \\
\hline & Biraz & 17 & 23,3 & 7 & 9,6 & 7 & 9,6 \\
\hline & Yok & 50 & 68,5 & 64 & 87,7 & 66 & 90,4 \\
\hline \multirow{3}{*}{ Oda Kapısı } & Fazla & - & - & - & - & - & - \\
\hline & Biraz & - & - & - & - & - & - \\
\hline & Yok & 22 & 100 & 22 & 100 & 22 & 100 \\
\hline
\end{tabular}

n: Kap1 sayısı, \%: Yüzdelik değer

Tablo I. Kemaliye evlerinin kapı kanatlarının bozulma durumu

Tablo1'deki sonuçlara genel olarak bakıldığında, kapılarda meydana gelen çatlamalar çürüme ve çarpılmaya nazaran daha fazladır. Özellikle bahçe kapılarında korunma durumunun zayıf olmasından ve dış hava şartlarına maruz kalmasından dolayı daha fazla bozulma durumu tespit edilmiştir. Kapılarda meydana gelen çatlama ve çarpılmalar genel olarak kanatlarda gözlemlenmiştir. Düşey olarak birleştirilen ahşaplardan oluşan kanatlar zamanla çatlamaya ve dış hava şartlarının etkisi ile çarpılmaya maruz kalmıştır. Kasalarda daha az çatlama ve çarpılma görülürken, kasa birleşim noktalarında ve kanatların uç noktalarında kısmen çürümeler gözlemlenmiştir. Giriş kapılarında bozulma oranları daha düşük seviyede iken oda kapılarında çürüme ve çatlama gözlemlenmemiştir.

\subsection{Kapıların Kanat Sayıları ve Ölçüleri}

Araştırılan Kemaliye evlerinin bahçe, giriş ve oda kapılarında kullanılan kanat sayıları Şekil 3'de verilmiştir. Buna göre, bahçe kapılarının \% 75'inde, giriş kapılarının \% 36,9'unda ve oda kapılarının ise \% 4,8'inde çift kanatlı kapıların kullanıldığı görülmektedir. İncelenen oda kapılarının yalnızca 1 'inde çift kanatlı kapı kullanılmıştır. 


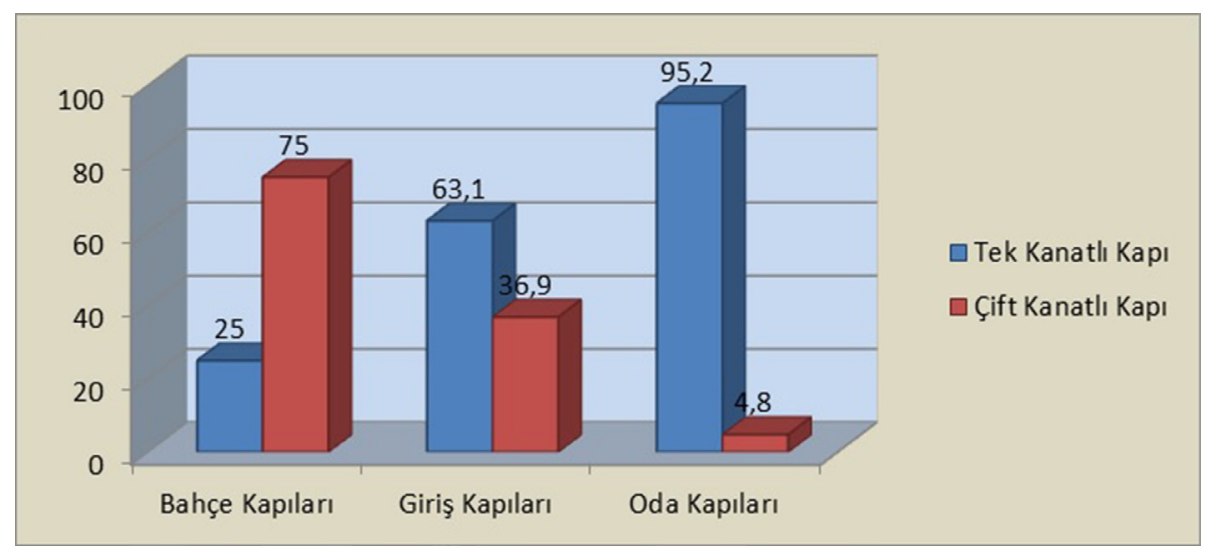

Şekil 3. Kemaliye evlerinin kapılarının kanat sayıları grafı̆gi

\begin{tabular}{|c|c|c|c|c|c|c|c|c|}
\hline \multirow{2}{*}{\multicolumn{2}{|c|}{ Kapı Kanadı Ölçüleri }} & \multicolumn{2}{|c|}{ Genişlik } & \multicolumn{2}{|c|}{ Yülkseklik } & \multicolumn{2}{|c|}{ Kalınlık } & \multirow{3}{*}{$\begin{array}{c}\begin{array}{c}\text { Toplam Kapı } \\
\text { Sayıs }\end{array} \\
7\end{array}$} \\
\hline & & \multirow{2}{*}{$\begin{array}{c}\bar{X} \\
98,3\end{array}$} & \multirow{2}{*}{$\begin{array}{c}S \\
19,62\end{array}$} & \multirow{2}{*}{$\frac{\bar{X}}{180,7}$} & \multirow{2}{*}{$\begin{array}{c}\mathrm{S} \\
12,14\end{array}$} & \multirow{2}{*}{$\frac{\bar{X}}{2}$} & \multirow{2}{*}{$\begin{array}{c}\mathrm{S} \\
0,41\end{array}$} & \\
\hline & Tek kanat & & & & & & & \\
\hline Danç Kapisi & Çift kanat & 141,8 & 19,07 & 190,5 & 10,38 & 2,3 & 0,51 & 21 \\
\hline \multirow{2}{*}{ Giriş Kapıs1 } & Tek kanat & 98,5 & 17,78 & 177,8 & 9,09 & 2,3 & 0,37 & 46 \\
\hline & Çift kanat & 136,8 & 18,85 & 193,6 & 10,92 & 2,5 & 0,54 & 27 \\
\hline \multirow{2}{*}{ Oda Kap1s1 } & Tek kanat & 90,89 & 5,52 & 174,5 & 5,92 & 1,96 & 0,34 & 20 \\
\hline & Çift kanat & 120 & 0 & 211 & 0 & 4 & 0 & 1 \\
\hline
\end{tabular}

Tablo 2. Kemaliye evlerinin kapılarının kanat ölçülerinin ortalama değerleri

Araştıılan Kemaliye evlerinin kapılarının kanat sayıları ve kanatların ortalama genişlik, yükseklik ve kalınlık ölçüleri Tablo 2'de verilmiştir.

Tablo 2'deki kapıların ortalama ölçülerine bakıldığında, tek kanatlı bahçe kapılarının genişliğinin 98,3 cm, giriş kapısının 98,5 cm ve oda kapısının ise 90,89 cm olduğu, tek kanatlı bahçe kapılarının yüksekliğinin 180,7 $\mathrm{cm}$, giriş kapısının $177,8 \mathrm{~cm}$ ve oda kapısının ise $174,5 \mathrm{~cm}$ olduğu ve tek kanatlı bahçe kapılarının kalınlığının $2 \mathrm{~cm}$, giriş kapısının $2,3 \mathrm{~cm}$ ve oda kapısının ise 1,96 cm olduğu görülmektedir. Bu sonuçlara göre, tek kanatlı bahçe ve giriş kapılarının genişlik ölçüleri ortalamasının aynı olduğu, bunlara göre oda kapısının genişliğinin yaklaşık $8 \mathrm{~cm}$ düştüğü vetek kanatlı her üç kapı türünün de ortalama yükseklik ölçülerinin ise yaklaşık 175-180 $\mathrm{cm}$ arasında değişiklik gösterdiği görülmektedir. Diğer taraftan, çift kanatlı 
bahçe kapılarının genişliğinin 141,8 cm ve giriş kapısının $136,8 \mathrm{~cm}$ olduğu, çift kanatlı bahçe kapılarının yüksekliğinin 190,5 cm ve giriş kapısının ise $193,6 \mathrm{~cm}$ olduğu ve yine çift kanatı bahçe kapılarının kalınlığının 2,3 cm ve giriş kapısının 2,5 cm olduğu görülmektedir.

Sonuçlara genel olarak bakıldığında, Kemaliye evlerinin bahçe ve girişi kapılarının kanat sayılarının değişkenlik gösterdiği görülmektedir. Çift kanatı kapılarda kapının sağa açıldığı durumlarda solda bulunan ihtiyaç halinde açılabilen kanat, genişlik olarak diğer kanada göre daha dar olarak tutulurken bazı evlerde ise kanat ölçüleri her iki kanatta eşittir. Kanatlar kasa boşluğuna göre birkaç santimetre daha uzun ve kasanın üzerine doğru kapanırken dışarıya doğru açılması engellenmiştir. İç mekânda kullanılan kapılarda özellikle mutfak kapılarının yükseklik ölçüsünün oda kapılarına göre daha az olduğu tespit edilmiştir. Yapılan yüz yüze görüşmelerde bu yükseklik farkının hane kullanıııarının nimete saygısından kaynaklandığı, mutfağa girerken kişinin eğilerek girmesi için alçak tutulduğu ifade edilmiştir.

Araştıılan Kemaliye evlerinin kapılarının kanat sayıları ve kapıların iç geçiş boşluklarının ortalama genişlik, yükseklik ve derinlik ölçüleri Tablo 3'de verilmiş̧ir.

\begin{tabular}{|c|c|c|c|c|c|c|c|c|}
\hline \multirow{2}{*}{\multicolumn{2}{|c|}{ Kapı Boșluğu Ölçüleri }} & \multicolumn{2}{|c|}{ Genişlik } & \multicolumn{2}{|c|}{ Yükseklik } & \multicolumn{2}{|c|}{ Derinlik } & \multirow{3}{*}{$\begin{array}{c}\begin{array}{c}\text { Toplam Kapı } \\
\text { Sayısı }\end{array} \\
7\end{array}$} \\
\hline & & \multirow{2}{*}{\begin{tabular}{|c|}
$\bar{X}$ \\
96,6
\end{tabular}} & \multirow{2}{*}{$\begin{array}{c}S \\
19,70\end{array}$} & \multirow{2}{*}{\begin{tabular}{|c|}
$\bar{X}$ \\
178,9
\end{tabular}} & \multirow{2}{*}{$\begin{array}{c}S \\
11,46\end{array}$} & \multirow{2}{*}{$\begin{array}{l}\bar{X} \\
11\end{array}$} & \multirow{2}{*}{$\begin{array}{c}S \\
1,27\end{array}$} & \\
\hline & Tek kanat & & & & & & & \\
\hline $\mathrm{s}$ & Çift kanat & 140,5 & 19,45 & 186,5 & 10,94 & 12,6 & 1,96 & 21 \\
\hline \multirow{2}{*}{ Giriş Kapıs1 } & Tek kanat & 96,4 & 17,66 & 175,3 & 9,26 & 12,3 & 1,95 & 46 \\
\hline & Çift kanat & 134,6 & 18,58 & 190,8 & 10,90 & 12,8 & 2,40 & 27 \\
\hline \multirow{2}{*}{ Oda Kapıs1 } & Tek kanat & 88,5 & 6,50 & 171,5 & 5,47 & 12 & 1,86 & 20 \\
\hline & Çift kanat & 117,5 & 0 & 204 & 0 & 14 & 0 & 1 \\
\hline
\end{tabular}

Tablo 3. Kemaliye evlerinin kapılarının iç geçiş boşluk ölçülerinin ortalama değerleri

Tablo 3'deki kapıların ortalama iç geçiş boşluk ölçülerine bakıldığında, tek kanatlı bahçe kapılarının geçiş boşluğu genişliğinin $96,6 \mathrm{~cm}$, giriş kapısının $96,4 \mathrm{~cm}$ ve oda kapısının ise $88,5 \mathrm{~cm}$ olduğu, tek kanatı bahçe kapılarının geçiş boşluğu yüksekliğinin 178,9 cm, giriş kapısının 175,3 cm ve oda kapısının ise $171,5 \mathrm{~cm}$ olduğu ve tek kanatlı bahçe kapılarının iç geçiş boşluğu derinliğinin $11 \mathrm{~cm}$, giriş kapısının $12,3 \mathrm{~cm}$ ve oda kapısının 
ise $12 \mathrm{~cm}$ olduğu görülmektedir. Ayrıca, mekân içine açıldığı belirlenen kapıların \%62,2'si sola doğru açıırken \%37,8'inin sağa doğru açıldığı tespit edilmiştir.

\subsection{Kapıların Yapım Tekniği}

Kemaliye evlerinde tüm kapılar çakma kapı sisteminde yapılmıştır. Düşey ahşaptan oluşan kapı kanatları kapının arkasında bulunan ahşap destek elemanına kabara denilen çivilerle tutturulmuştur. Bu çiviler bağlantıyı sağlamlaştırmakla beraber başlık kısmının daha büyük, yivli ve dairesel oluşu kapılara görsel güzellik katmaktadır. Kapının ön yüzünde ise düşey ahşap biniler kullanılmıştır. Bu binilerden kanatların birleşme kısmına denk gelen ve diğer ahşap elamanlara göre daha geniş olarak kullanılanı kanatlar arasındaki boşluğun görülmemesini sağlamaktadır (Şekil 5, 6, 8, 9, Bkz. Ekler). Kasalar birbirinin üzerine binecek şekilde üstten çivi ile tutturulmuş bazı evlerde ise 45 derece gönye burun birleştirme yapıldığı gözlemlenmiştir. Eşikte açılan $4 \times 4 \mathrm{~cm}$ 'lik boşluğa kapı kasalarının alt kısmında oluşturulan çıkıntı sabitlenmiştir. Kapı kanatları güllap ile kasaya bağlanırken kasasız kapıya rastlanmamıştır. Kapı kanatları üzerinde simgesel motiflerle bezeli kapı tokmakları bulunmaktadır (Şekil 4, Bkz. Ekler).

\subsection{Kapılarda Kullanılan Ahşap Malzeme}

Kemaliye evlerinin cephelerinde ahşabı koruma amaçlı sac kullanılması ve özellikle güneş ışınları sebebiyle kararma meydana gelmesi kullanılan ahşap malzemenin türünü belirlemede önemli bir zorluk oluşturmuştur. Mevcut halini koruyan evlerin kapılarında kullanılan malzemeden örnek alınarak inceleme yapılması gerekli olduğundan kullanılan ahşap malzemenin türü sözlü ve yazılı kaynaklar üzerinden tespit edilmiştir. Kemaliye'de ormanlık arazinin olmayışı yalnızca cılız meşeliklerden oluşan ağaç topluluklarından dolayı ahşap malzeme ihtiyacı Refahiye ve Göle'de bulunan ormanlardan karşılanmıştır. Refahiye Kemah güzergâhından temin edilen tomruklar ceviz ve özellikle sarıçamdır. Cephe kaplamalarında kullanılan çam, kapı ve pencerelerde de kullanılmıştır. Bazı kapılarda ceviz ağacının da kullanıldığı tespit edilmiştir. Restorasyonu yapılan evlerde kaplamalarla birlikte bazı pencereler ve kapılarda değiştirilmiştir. Onarım sonrası genel olarak sarıçam malzeme olarak tercih edilmiştir. Emprenye edilerek kullanılan bu malzemeye koruyucu boya veya yalnızca vernik uygulaması yapıldığı görülmüştür. Yakın yıllarda yapılan restorasyon çalışmalarında sıklıkla yalnızca vernik kullanıldığı gözlemlenmiştir. 


\section{Sonuç ve Öneriler}

Araştırma kapsamına alınan Kemaliye evlerinin kapılarıyla ilgili elde edilen sonuçlar ve öneriler aşağıda verilmiştir.

Metal kapı ile değiştirilen özgünlüğünü yitirmiş olan kapıların dışında ahşap kapıların hepsinde tokmak bulunduğu gözlemlenmiştir. İslamiyet sonrası mahremiyetin etkisiyle şekillenen ince ve tok ses çıkaran çift kapı tokmağı örneği Anadolu'nun birçok bölgesinde olduğu gibi Kemaliye'de bulunan geleneksel konutlarda da bulunmaktadır. Kapıların tümü çakma sistemi ile yapılmış olup güllap adı verilen menteşe görevi gören bağlayıcı eleman kullanılmıştır. Kapıların kanadında yatay destek elemanı ile kanat arasında bağlantıyı sağlayan kabara adı verilen çiviler simetrik olarak kullanılmıştır. Oda kapıları Geleneksel Türk evlerinde olduğu gibi odanın köşelerine konuşlandııımıştır. Kapılar Geleneksel Türk evi kapılarının özelliklerini yansıtmaktadır. Kemaliye'de görülen bu kapı tipinin benzerleri özellikle Safranbolu, Cumalikızık, Yörükköy (Safranbolu), Beypazarı ve Anadolu'nun bazı bölgelerinde görülmektedir.

Kapılarda kullanılan metal öğelerin korozyon sonucu bozulduğu gözlemlenmiştir. Bu kapsamda kullanılan metal öğelerin sağlamlaştırıması ve koruyucu önlemlerin alınmasında büyük yarar görülmektedir.

Bahçe kapılarında çatlama, çarpılma ve çürüme oranı giriş ve oda kapılarına göre daha fazladır. Oda kapılarında ise herhangi bir bozulma durumu gözlemlenmemiştir. Bu durum dış hava şartlarıyla ilişkilendirilebilir. Koruyucu saçak bulunmayan bahçe kapılarında bozulma durumu daha hızlı ve daha yüksek oranlı olarak tespit edilmiştir. Bu bağlamda, bahçe kapılarının belirli onarımdan geçmesi ve koruyucu saçak örtünün mümkün olduğunca kullanılması gerekmektedir. Giriş kapılarında çatlama, çarpılma ve çürüme bahçe kapılarına nazaran daha az olmasına karşın yine de gerekli önlemlerin alınmasında yarar görülmektedir.

Evlerin tek kanatlı bahçe kapılarının genişlik ölçüleri ortalamasının 98,3 $\mathrm{cm}$, giriş kapısının 98,5 cm ve oda kapısının ise $90,89 \mathrm{~cm}$ olduğu, tek kanatlı bahçe kapılarının yükseklik ölçülerinin 180,7 cm, giriş kapısının $177,8 \mathrm{~cm}$ ve oda kapısının ise $174,5 \mathrm{~cm}$ olduğu ve tek kanatlı bahçe kapılarının kalınlığının $2 \mathrm{~cm}$, giriş kapısının 2,3 cm ve oda kapısının ise $1,96 \mathrm{~cm}$ olduğu tespit edilmiştir. Bu sonuçlara göre tek kanatlı bahçe ve giriş kapılarının genişlik ölçüleri ortalamasının aynı olduğu, bunlara göre oda kapısının yaklaşık $8 \mathrm{~cm}$ daha dar olduğu ve tek kanatı her üç kapı türünün de ortalama yükseklik ölçülerinin ise yaklaşık $175-180 \mathrm{~cm}$ arasında değişiklik gösterdiği belirlenmiştir. Diğer taraftan, çift kanatlı 
bahçe kapılarının genişlik ölçülerinin $141,8 \mathrm{~cm}$ ve giriş kapısının 136,8 cm olduğu, çift kanatlı bahçe kapılarının yükseklik ölçülerinin 190,5cm ve giriş kapısının ise 193,6 cm olduğu ve yine çift kanatı bahçe kapılarının kalınlık ölçülerinin 2,3 cm ve giriş kapısının 2,5 cm olduğu tespit edilmiştir. Bu kapıların ortalama genişlik ölçülerinin günümüz kapı ölçüleriyle uyum içinde olduğu, fakat bu çalışmada belirlenen 175-180 cm kapı yükseklik ölçüleri ile günümüz 200-220 cm kapı yükseklik ölçüleri arasında belirgin bir farklılık görülmektedir (TS 2255, 1976). Bu farklılık kapı kanadı kalınlık ölçülerinde de göze çarpmaktadır.

Cephelerin üst yüzey işlemlerinde görülen farklı çalışmalar ve kullanılan malzeme çeşitliliği sonucu oluşan farklı görüntülere sahip ev cepheleri pencere ve kapıların tamamlayıcı unsur olmasından dolayı görünüş açısından olumsuzluk oluşturmaktadır. Bu konuyla ilgili Kemaliye belediyesi ve vakıflar bölge müdürlüğü tarafından yapılan toplantıda uygulanan üst yüzey işlemlerinin çeşitliliği sonucu oluşan renk bütünlüğü sorunu çözümlenme aşamasına henüz ulaşamamıştır. Konuyla ilgili ahşap ustalarından ve ilçede bulunan meslek yüksek okuluna bağlı mimari restorasyon bölümü akademisyenlerinden fikirler alınarak bundan sonraki restorasyon çalışmaları şekillendirilmelidir. Yapılacak restorasyon çalışmalarında orijinalliklerin bozulmamasına özen gösterilmelidir. 


\section{Kaynakça}

Alper, B. (1990). Kemaliye Yerleşme Dokusu ve Evleri Üzerine Bir Araştırma, Doktora tezi, İstanbul Teknik Üniversitesi Fen Bilimleri Enstitüsü, İstanbul.

Eldem, S. H. (1955).Türk Evi Plan Tipleri. İstanbul: iTü yayınları.

Hacıbaloğlu, M. (1989). Geleneksel Türk Evi ve Çağımıza Ulaşamamasının Nedenleri. G.Ü. Müh. Mim. Fak. Yayınları, Ankara, I-35.

Kahraman, N. (2004). Geleneksel Afyonkarahisar Evlerine Ait Kapıların Incelenmesi, Yüksek Lisans Tezi, G.Ü. Fen Bilimleri Enstitüsü, Ankara.

Kılıç, E. (2010). Geleneksel Mardin Evlerine Ait Ahşap Kapıların Malzeme ve Yapım Tekniği Bakımından Incelenmesi. Yüksek Lisans Tezi, Gazi Üniversitesi Fen Bilimleri Enstitüsü, Ankara.

Küçükerman, Ö., Güner, Ş. (1995). Anadolu Mirasında Türk Evleri. İstanbul: T.C. Kültür Bakanlığı Yayınları.

İzgi, U., Aysel, B.B. (2003). Kapılar ve Hafif Bölmeler. İstanbul: Yem Yayınları.

Öztürk, M. (2003). Anadolu Ahşap Kapılarından Seramik Sanatına ve Tekniklerine Göndermeler. Yüksek Lisans Sanat Eseri Çalışması Raporu, Hacettepe Üniversitesi Sosyal Bilimler Enstitüsü, Ankara.

Parlar, G. (Ekim 2002). “Kaybolan Kültür Değerlerimizden Afyonkarahisar’ da Bulunan Alibey Konağı ile ilgili Mimari Özellikleri ve Süslemeleri Üzerine Bir Araştırma”, VI. Afyonkarahisar Araştırmaları Sempozyumu, Afyonkarahisar .

Şaşmaz, H.A. (2002). Ankara Merkez ve Ayaş, Beypazarı İlçelerinde Geleneksel Türk Evi Kapılarının Analizi. Yüksek Lisans Tezi, Gazi Üniversitesi Fen Bilimleri Enstitüsü, Ankara.

T.C. Kemaliye Kaymakamlığı, (1996). Her Yönüyle Kemaliye (Eğin) Doğu Anadolu Coğrafyasında Kemaliye. Erzincan: T.C. Kemaliye Kaymakamlı̆̆ı Köylere Hizmet Götürme Birliği.

TS 2255, (1976). Kapılar - Terimler, Türk Standartları Enstitüsü, Ankara.

Yıldırım, K. (2006). Geleneksel Afyonkarahisar Evlerine Ait Kapılar Üzerine Bir Araştırma. Gazi Üniversitesi Müh. Mim. Fak. Dergisi, 2 I (I).

Yıldırım, K., Kahraman, N. ve Hidayetoğlu, M.L. (November 2006)). Geleneksel Afyonkarahisar Evlerine Ait Kapıların Incelenmesi, 9th International Symposium of Traditional Arts, İzmir. 


\section{Görsel Kaynaklar}

Şekil I-2-3-4-5-6-7-8-9-10: Keskin, S. (2016). Geleneksel Kemaliye Evlerine Ait Ahşap Kapı ve Pencerelerin Incelenmesi, Yayımlanmamış Yüksek Lisans Tezi, Gazi Üniversitesi Fen Bilimleri Enstitüsü, Ankara.

Tablo I-2-3-4: Keskin, S. (20/6). Geleneksel Kemaliye Evlerine Ait Ahşap Kapı ve Pencerelerin Incelenmesi, Yayımlanmamış Yüksek Lisans Tezi, Gazi Üniversitesi Fen Bilimleri Enstitüsü, Ankara.

\section{Ekler}

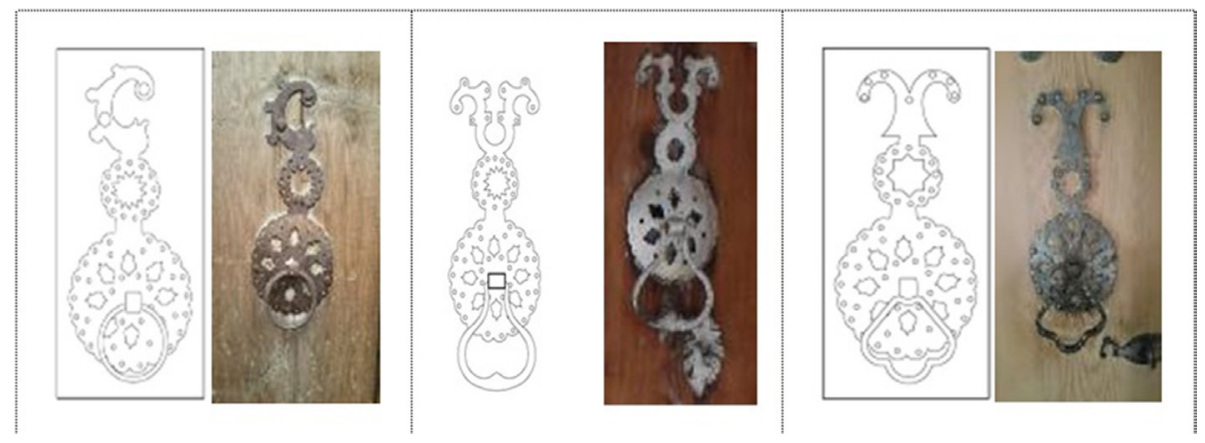

Şekil 4. Geleneksel Kemaliye evlerine ait kapı tokmağı örnekleri 

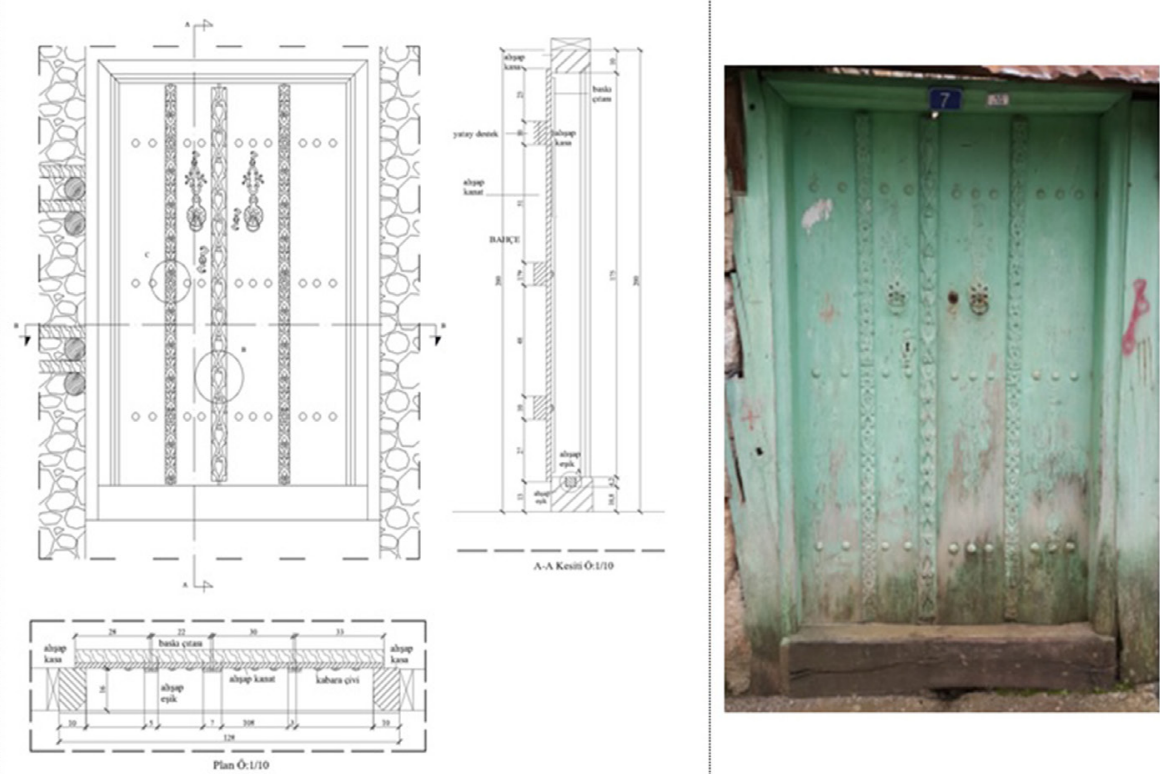

Şekil 5. Geleneksel Kemaliye Ali Necati Kaya Evi Süslemeli Bahçe Kapısı
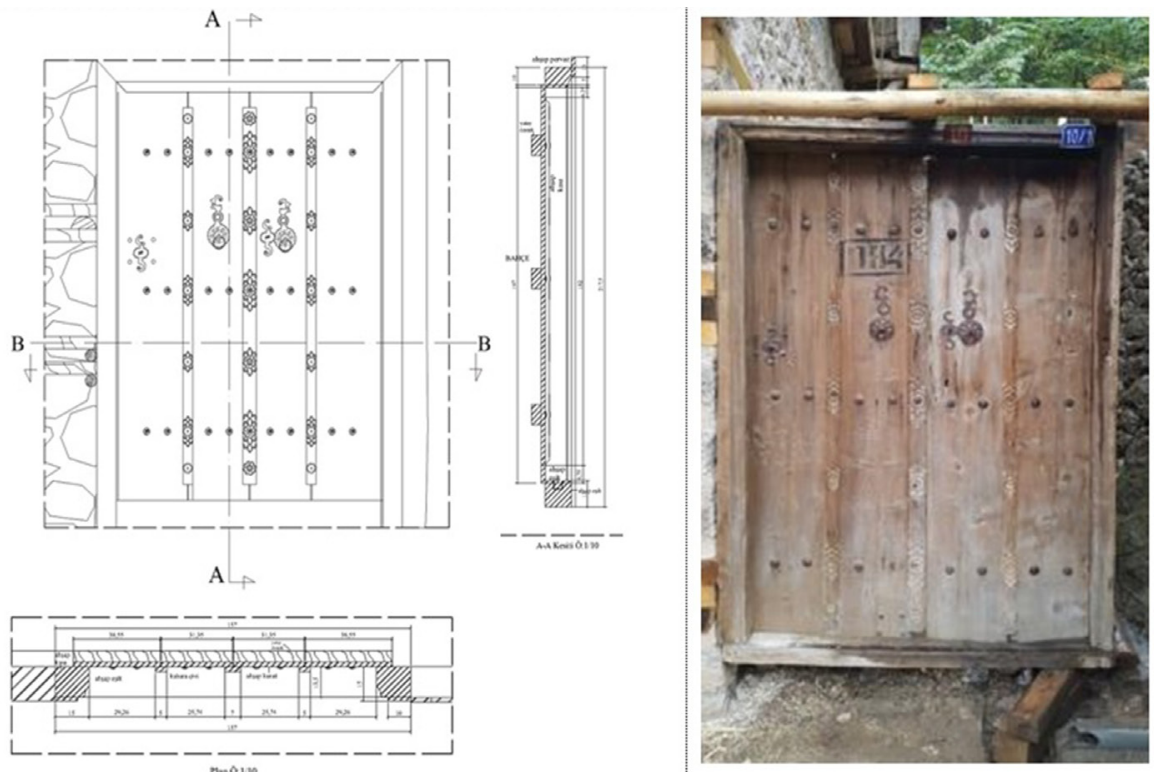

Şekil 6. Geleneksel Kemaliye Hatice Türkmen Evi Süslemeli Bahçe Kapısı 

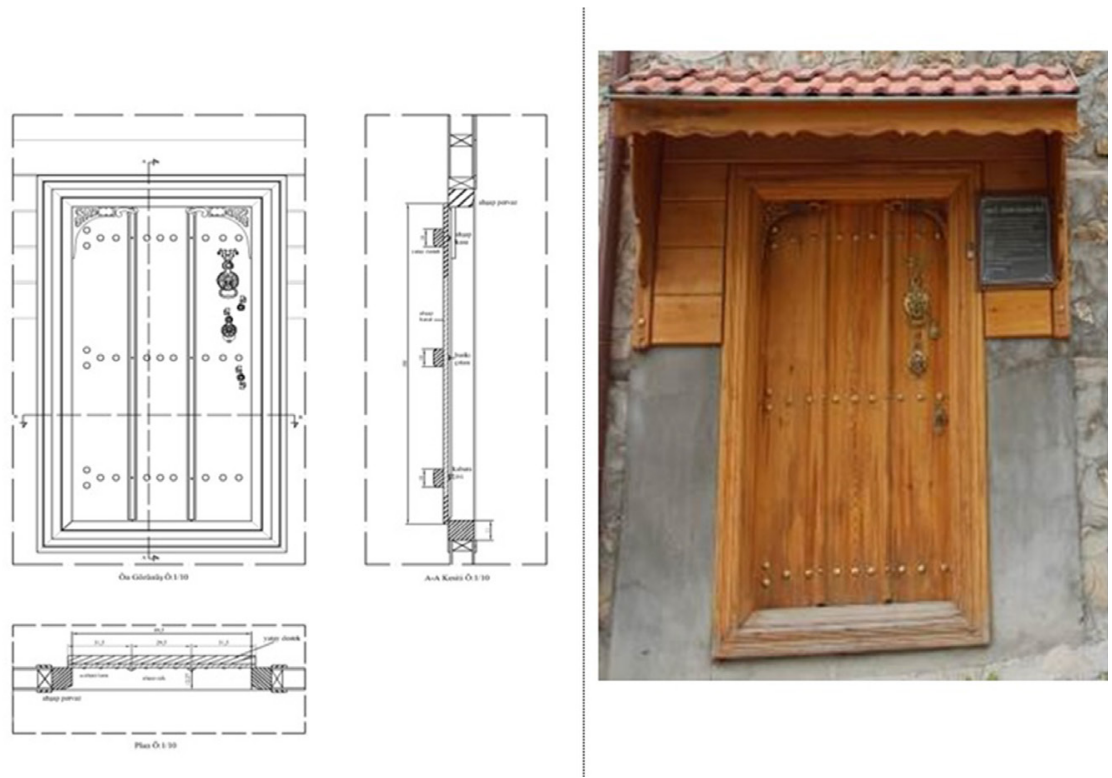

Şekil 7. Geleneksel Kemaliye Hilmi Balioğlu Evi Tek Kanatlı Giriş Kapısı
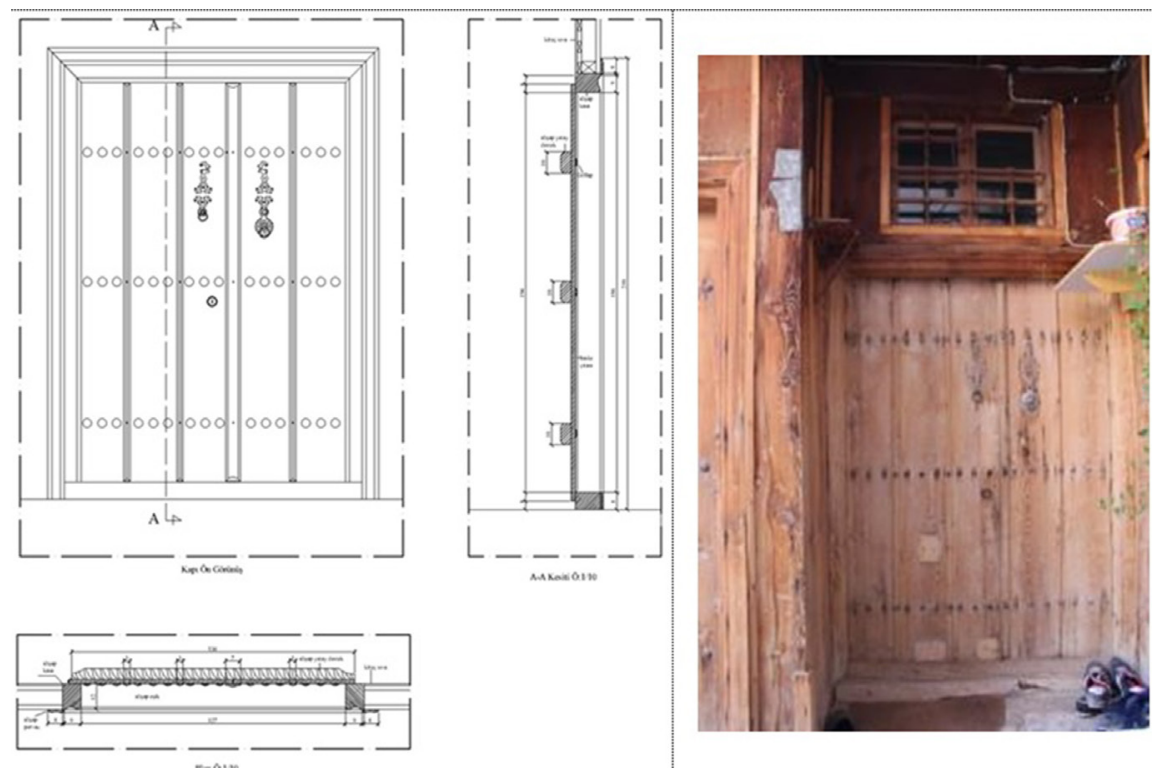

Şekil 8. Geleneksel Kemaliye Hüseyin Avni Güven Evi Çift Kanatlı Giriş Kapısı 

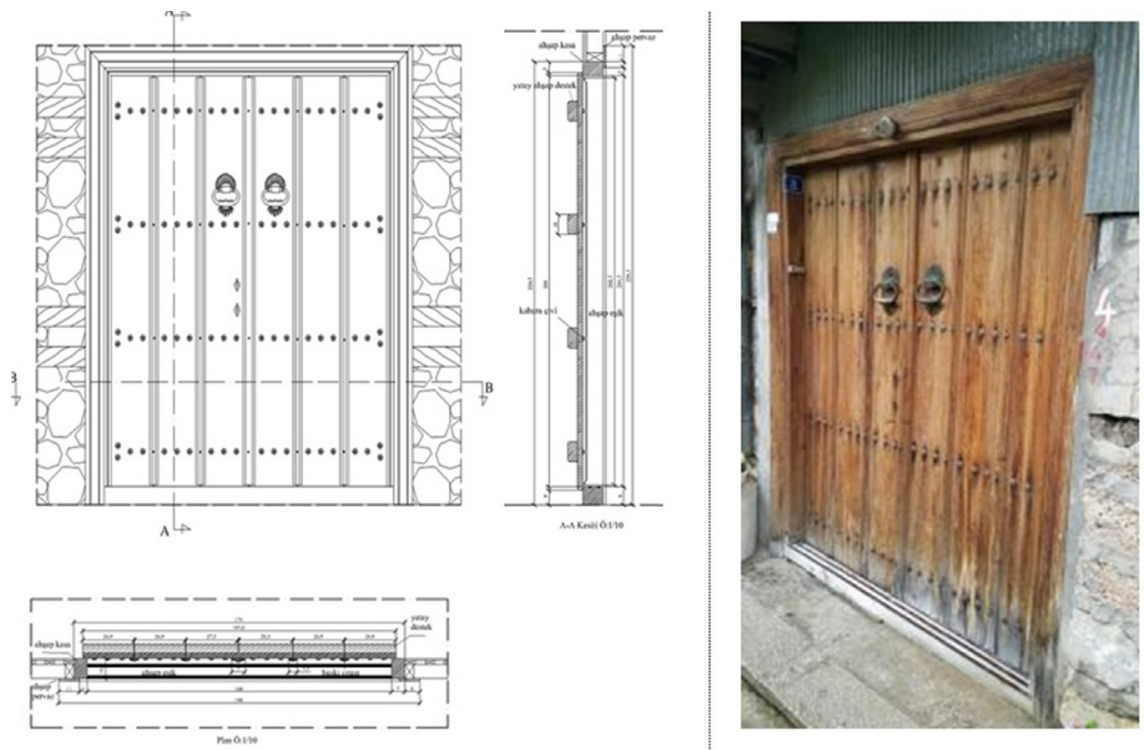

Şekil 9. Geleneksel Kemaliye Şadi Yaşar Evi Çift Kanatı Giriş Kapısı
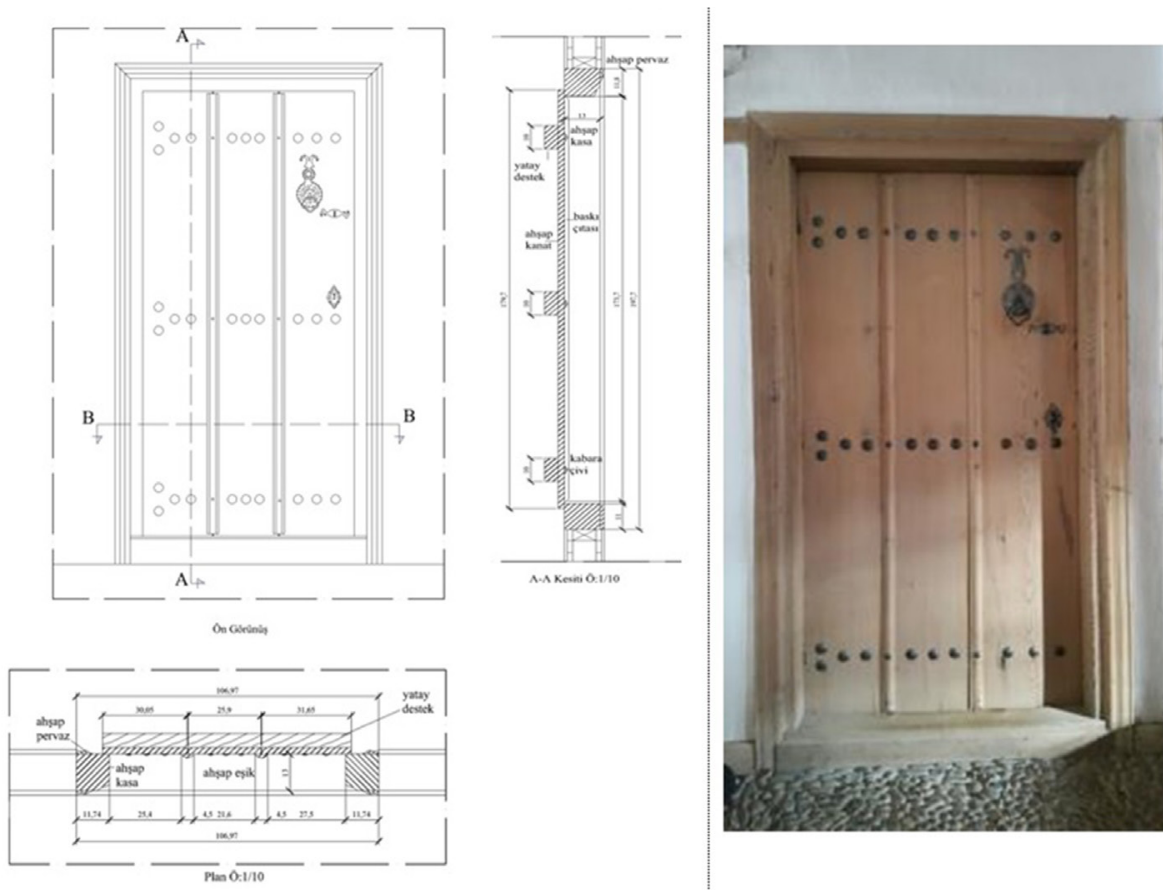

Şekil I0. Geleneksel Kemaliye Tevfik Eryiğit Evi Oda Kapısı 


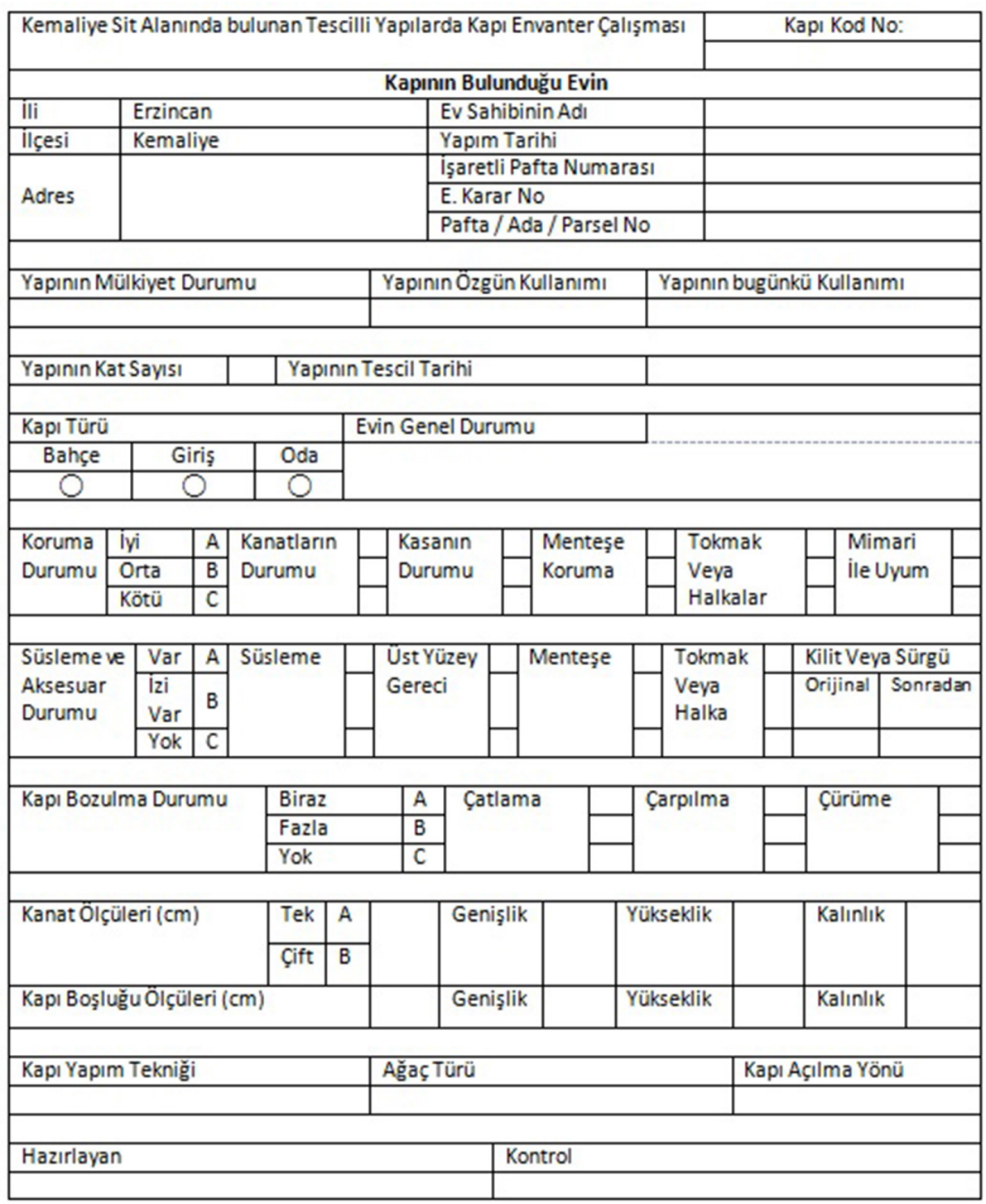

Tablo 4. Araştırmada Kullanılan Envanter Form Orneği 